\title{
Effect of military activity on butterfly (Lepidoptera) communities in Korea: Conservation and maintenance of red listed species
}

\author{
Sung-Soo KIM ${ }^{1}$, TAE-Sung KWON ${ }^{2}$ and CheOl Min LEE ${ }^{3, *}$ \\ ${ }^{1}$ Research Institute for East Asian Environment and Biology, 293-27 Amsa 3 dong, Angdong-gu, Seoul 143-203, Republic of Korea; \\ e-mail: nabifri@chol.com \\ ${ }^{2}$ Division of Forest Insect Pests and Diseases, Korea Forest Research Institute, 57 Hoegi-ro, Dongdaemun-gu, Seoul 130-712, \\ Republic of Korea; e-mail: insectcom@chol.com \\ ${ }^{3}$ Center for Forest and Climate Change, Korea Forest Research Institute, 57 Hoegi-ro, Dongdaemun-gu, Seoul 130-712, \\ Republic of Korea; e-mail: leecheolmin77@gmail.com
}

Key words. Lepidoptera, butterflies, red listed species, military training area, grassland, conservation

\begin{abstract}
Military training areas are increasingly recognized as areas of high biodiversity and habitats for many wild organisms, including threatened or endangered species. However, the information on the ecological value of military training areas is limited because it is difficult access these sites. The aim of this study is to evaluate the effect of military activity on butterfly communities. The survey was carried out in a military training area (MTA) at Inje-gun near the demilitarized zone (DMZ), Inje forest (IJF) a secondary forest and Gwangneung forest (GWF) an old growth forest, from April to October 2008 to 2011. IJF and GWF were selected in order to determine the characteristics of a butterfly community differed in a MTA. Butterfly communities differ greatly among sites. Estimated species richness and species diversity were significantly higher in MTA compared to GWF. Grassland species were abundant in MTA and forest interior species in GWF. Species richness and abundance of red listed species, especially grassland species, were greatest in MTA, but absent in GWF. Military activities were beneficial for red listed grassland species because they maintained an open habitat, which is rare elsewhere in current Korea. This study indicates that MTAs are important in terms of conservation and in providing a refuge for red listed grassland species.
\end{abstract}

\section{INTRODUCTION}

Military training areas (MTA) are increasingly recognized as areas of high biodiversity and habitats for many wild organisms, including threatened or endangered species (Smith et al., 2002; Althoff et al., 2004; Warren et al., 2007; Warren \& Büttner, 2008). They have often been transformed into legally protected nature conservation areas (IUCN, 1996). For example, all nations within the EU are required to designate a certain percentage of their landmass as "special areas of conservation" to be included in the Natura 2000 network (EUROPA, 2014). Nominations are based on a high biodiversity and the occurrence of red listed species and priority habitats. Noting that their military training lands have these characteristics, Denmark has nominated $45 \%$ of its military area, the Netherlands and Germany 50\%, and Belgium 70\% (Gazenbeek, 2005; Warren et al., 2007; Jentsch et al., 2009). Typical military areas include those used for maneuvers by large, tracked and wheeled vehicles that can traverse thousands of hectares in a single training exercise (Smith et al., 2002; Quist et al., 2003). These activities have effects ranging from minor soil compaction and flattening of standing vegetation to severe compaction and complete loss of vegetative cover in areas where the activity is highest (Wilson, 1988; Milchunas et al., 2000). However, MTAs often encompass large tracts of land that are protected from intensive ag- riculture and urban development (Quist et al., 2003; Reif et al., 2011). Some MTAs are larger than many national parks and refuges, are often relatively isolated and have experienced little or no urbanization (Cohn, 1996). In addition, the frequency, extent and intensity of the disturbance caused by military activity results in a mosaic of different successional stages. However, the information on the ecological value of MTAs is limited as public access is restricted because of unexploded bombs.

Following the Korean War many military camps and MTAs were established in South Korea (Hong, 2008) along with a Demilitarized Zone (DMZ) between North and South Korea in 1953 (Byun et al., 2005; National Institute of Environmental Research, 2012). The width of the DMZ is $2 \mathrm{~km}$ on both the northern and southern sides of the Korean Military Demarcation Line. It is recognized as a highly important area internationally and domestically, in terms of the biodiversity there with rare species, endangered wild species and natural monuments (Ministry of Environment, 2014). Many military camps and military training areas located around the DMZ play an important role in keeping landscapes open due to various military activities including large-vehicle maneuvers. However, Korea has successful reforested, which led to a decline in open landscapes. Grasslands greatly decreased and currently only account for $0.4 \%(39,371$ ha) of the total land mass in

\footnotetext{
* Corresponding author.
} 


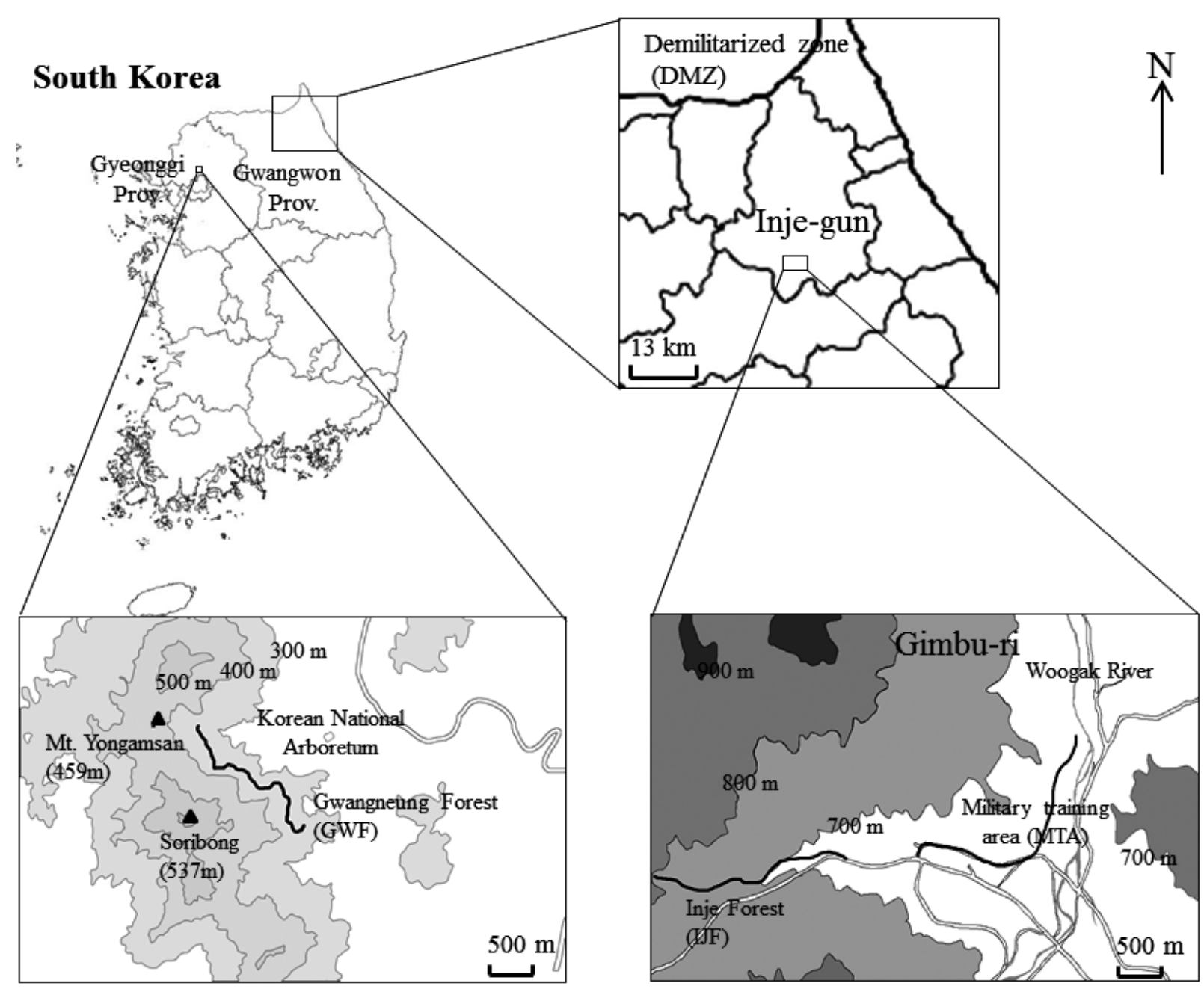

Fig. 1. Map showing the locations of the sites studied. Bold lines indicate each transect.

Korea (Ministry of Land, Transport and Maritime Affairs, 2011). This environmental change will affect the distribution and abundance of organisms in the forest ecosystem. It is likely that some rare species or endangered grassland species have survived in grassland formed by military activity. However, little scientific research or monitoring is permitted on military land.

Butterflies are one of the most popular elements of wildlife and flagships of biodiversity (Nakamura, 2011). Butterflies are a good indicator group, because their populations respond more rapidly to adverse environmental change than longer lived organisms (Thomas et al., 2004). Butterflies are known to respond to global warming (e.g. Kwon et al., 2014), urbanization (e.g. Lee et al., 2015), agricultural intensification (e.g. van Swaay et al., 2010), and change in land use (e.g. Smith et al., 2002). Butterfly communities are greatly affected by changes in vegetation, because most butterfly larvae have strong associations with their host plants and adults require a specific range of nectar plants (Thomas, 1995; Honda \& Kato, 2005; Lee et al., 2015). In addition, the taxonomy and life histories of most Korean species are already well known and the adults of many species can be reliably identified in the field (Kim \& Seo, 2012; Kim et al., 2012; Lee et al., 2015).
This study provides a better understanding of how military activity can influence native organisms. In order to understand the ecological role of MTAs, the butterfly community in a MTA was compared with those in conservation areas in Inje forest (IJF) a secondary forest, and Gwangneung forest (GWF). We tested the following hypotheses: (1) Species richness and diversity of butterflies in the MTA are higher than those in IJF and GWF; (2) The butterfly community in the MTA differs from those in INJ and GWF; (3) grassland species are more abundant in the MTA and forest interior species in GWF; (4) red listed species are more abundant in the MTA than in INJ and GWF.

\section{MATERIAL AND METHODS}

\section{Study sites}

In Korea, military camps and training areas are strictly off-limits to civilians. It is almost impossible to survey them due to the many trenches, minefields and unexploded bombs. However, one of our long-term survey areas for butterflies was rapidly changed into a military training area. The expectation was that the environment would be greatly changed by the military activity so we immediately carried out a butterfly survey in secondary forest, Inje forest (IJF), which is adjacent to the military training area (MTA). Although replication in ecological studies is important, it is impossible to survey several military training areas in Korea. 
This MTA will also soon become off-limits to civilians. We arranged to collect data that are rarely recorded for military training areas. Gwangneung forest (GWF), which is one of the most famous conservation areas, was selected to clarify the characteristics of the butterfly community in the MTA. We conducted a butterfly survey using line transects at three study sites (Fig. 1).

$\operatorname{MTA}\left(37^{\circ} 54^{\prime} \mathrm{N}, 128^{\circ} 20^{\prime} \mathrm{E}\right)$ is used for military maneuvers with tanks and armored vehicles and not accessible to the general public. There are clear cuttings in forests in MTAs with open habitats maintained by continuous shelling and the movement of military vehicles. The most important herbaceous plants are Trifolium repens, Aster yomena and Lysimachia barystachys. The butterfly survey in the MTA was conducted along a dirt road of about 2 $\mathrm{km}$ in length. IJF $\left(37^{\circ} 55^{\prime} \mathrm{N}, 128^{\circ} 20^{\prime} \mathrm{E}\right)$, secondary forest, is located adjacent to the MTA. IJF is used as a control for measuring any change in butterfly communities in response to military activity. The major species of trees are Quercus mongolica, Pinus densiflora and Sorbus alnifolia. The butterfly survey in IJF was conducted along a forest road of about $2 \mathrm{~km}$ in length. GWF $\left(37^{\circ} 44^{\prime} \mathrm{N}, 127^{\circ} 9^{\prime} \mathrm{E}\right)$ has been protected and managed since it was designated as the mausoleum forest of King Sejo in 1468 (Korea National Arboretum, 2008). Most Korean forests are re-growth forests after being damaged by war or reckless deforestation, but GWF has been consistently managed for about 450 years (Korea National Arboretum, 2014). GWF is older than 100 years and composed mainly of Quercus serrata and Carpinus laxiflora (Lee et al., 1990). The butterfly survey in GWF was conducted along a forest road of about $2 \mathrm{~km}$ in length, and included the "long-term ecological research" (LTER) site of the Korean Forest Research Institute.

\section{Butterfly surveys}

These surveys were carried out using line transects (Yamamoto, 1975; Pollard \& Yates, 1993). We recorded the species and the number of individuals of all butterflies observed within $10 \mathrm{~m}$ of each transect. This method has been extensively used to survey and monitor butterfly communities (Honda \& Kato, 2005; Clark et al., 2007; Lee et al., 2014). The surveys were conducted during the adult flight season once a month from April to October in 2008 to 2011. In total, 28 surveys were carried out at each site. The butterfly surveys were carried out when the weather was fine and there were no clouds. The butterflies that we could not identify by sight were caught using sweep nets and then released after identification.

\section{Habitat type and red listed species}

Butterflies were classified based on habitat type they occupied. Habitat type was that of their larvae and they were classified as either grassland (GL), forest edge (FE) or forest interior species (FI). If a species occupied more than one habitat, the habitat recorded for it was the more frequently utilized habitat. Red listed species were classified as endangered (EN), vulnerable (VU) or near threatened species (NT). The classification of red listed species was based on red data book of endangered insects in Korea I (National Institute of Biological Resources, 2012).

\section{Landscape pattern}

Vegetation surveys could not be carried out because of unexploded bombs. Aerial photographs (Samah Aerial Survey Co) were used to compare environmental patterns of the surrounding environment along each transect at the different sites studied. The aerial photograph of the MTA and IJF was taken on 23 May 2013 and of GWF on 13 May 2011. The resolution of the aerial photographs was $28 \mathrm{~cm}$. The environment $100 \mathrm{~m}$ on either side of the survey transects were classified as either: forest, open land, river, dirt road or asphalt road.

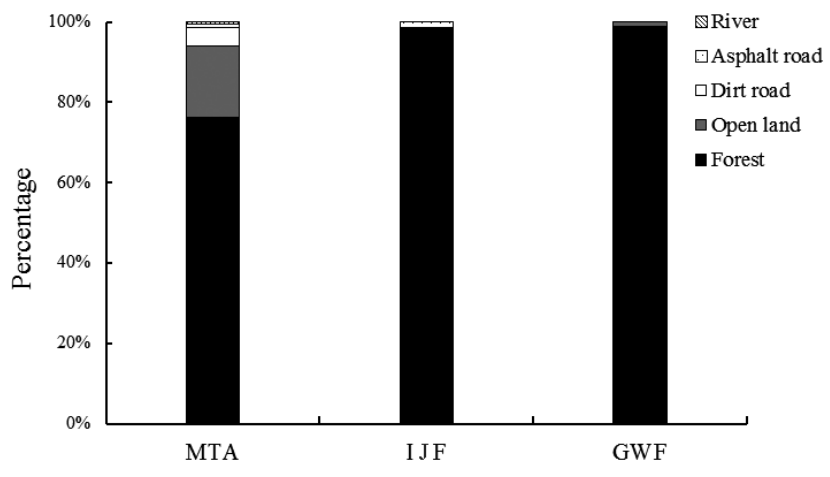

Fig. 2. Percentage of the surrounding area along each transect covered by different environmental features.

\section{Data analysis}

Species richness (number of species) and species diversity were evaluated using "Estimate S" (Colwell, 2005). Species richness was estimated using "Chao 1" (Heltshe \& Forrester, 1983; Palmer, 1990) and species diversity was estimated using the Shannon diversity index (Shannon \& Weaver, 1949). Species richness (Chao 1) and species diversity $\left(H^{\prime}\right)$ obtained using Estimate $\mathrm{S}$ were compared using a two-sample $t$-tests (Zar, 1999). $\chi^{2}$ tests were used to compare differences in species richness and abundance in the same habitats at the different sites studied (Zar, 1999). The structure of butterfly communities and the effect of landscape were determined using detrended correspondence analyses (DCA; Hill \& Gauch, 1980). We used unconstrained DCAs to determine the variation in the complete species data and avoid the problem of local minima occurring in nonmetric multidimensional scaling (Leyer \& Wesche, 2007). DCA was conducted using PC-ORD (ver. 6.0) (McCune \& Mefford, 1999). Statistical analyses were performed using STATISTICA ver. 8.0 (StatSoft Inc., 2004).

\section{RESULTS}

A total of 3,151 butterflies belonging to 112 species were recorded (Appendix 1). 1,956 individuals of 82 species were recorded in the MTA, 383 individuals of 62 species in IJF and 812 individuals of 57 species in GWF. In the MTA, Colias erate was the most abundant, comprising $16.5 \%$ of the total number of individuals. Cupido argiades (11.8\%), Ypthima argus (8.4\%) and Polygonia c-aureum (7.0\%) were also abundant. These four species comprised $44 \%$ of the total number of individuals. In IJF, Pieris napi $(10.7 \%)$, Thymelicus leoninus (6.3\%) and Lethe diana (5.7\%) were most abundant. In GWF, Libythea lepita $(25.2 \%)$ was most abundant, followed by Pieris melete (14.2\%) and Argynnis paphia $(11.5 \%)$. The dominant species differed significantly at the different sites.

The landscape surrounding the survey routes are shown in Fig. 2. Forest accounted for more than $98 \%$ at IJF and GWF, whereas open land accounted for $18 \%$ at the MTA.

Estimated species richness was significantly higher in the MTA than IJF and GWF (MTA vs. IJF: $t=4.64, d f=54, P$ $<0.001$; MTA vs. IJF: $t=6.71, d f=54, P<0.001$; Fig. 3 ). Estimated species richness was similar in IJF and GWF $(t$ $=1.92, d f=54, P=0.06)$. Species diversity was similar in MTA and IJF $(t=-1.07, d f=54, P=0.29)$. However, species diversity was significantly lower in GWF than MTA 

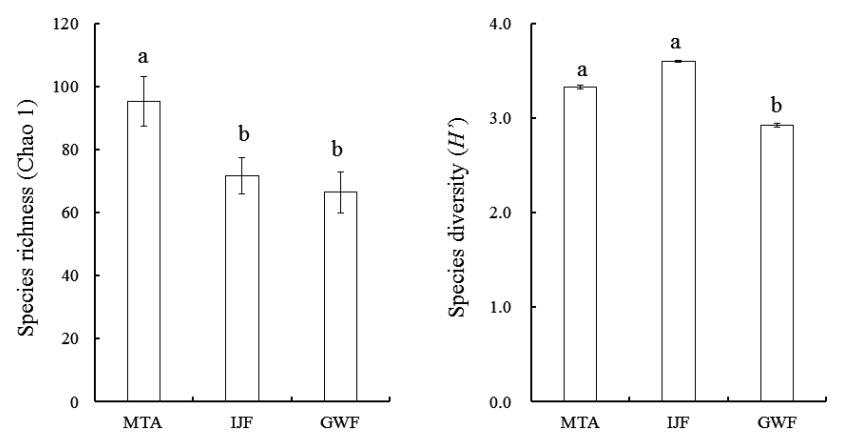

Fig. 3. Estimated species richness (Chao 1) and species diversity $\left(H^{\prime}\right)$ of butterflies recorded along each transect. Species richness and species diversity were calculated using Estimate $\mathrm{S}$ (Colwell et al., 2004). Different letters on the bars indicate significant differences between sites based on $t$-tests. Error bars of species richness (Chao 1) and species richness indicate one standard deviation.

and IJF (GWF vs. MTA: $t=5.73, d f=54, P<0.001$; GWF vs. IJF: $t=5.44, d f=54, P<0.001)$.

The comparison of species richness and abundance of habitat type is shown in Fig. 4. Species richness was similar in MTA and IJF $\left(\chi^{2}=0.50, d f=2, P=0.778\right)$. However, species richness differed significantly in MTA and GWF $\left(\chi^{2}=17.86, d f=2, P<0.001\right)$ and between IJF and GWF $\left(\chi^{2}=11.38, d f=2, P=0.003\right)$. Abundance differed significantly in the different sites studied $\left(\chi^{2}=138.66-1175.34\right.$, $d f=2, P<0.001)$.

Species richness and abundance of red listed species were highest in the MTA and absent in the GWF (Fig. 5). Of the red listed species recorded, one endangered species (EN), eight vulnerable species (VU) and four near threatened species (NT) were recorded in the MTA. One EN, seven VU and one NT were recorded in the IJF. Melitaea

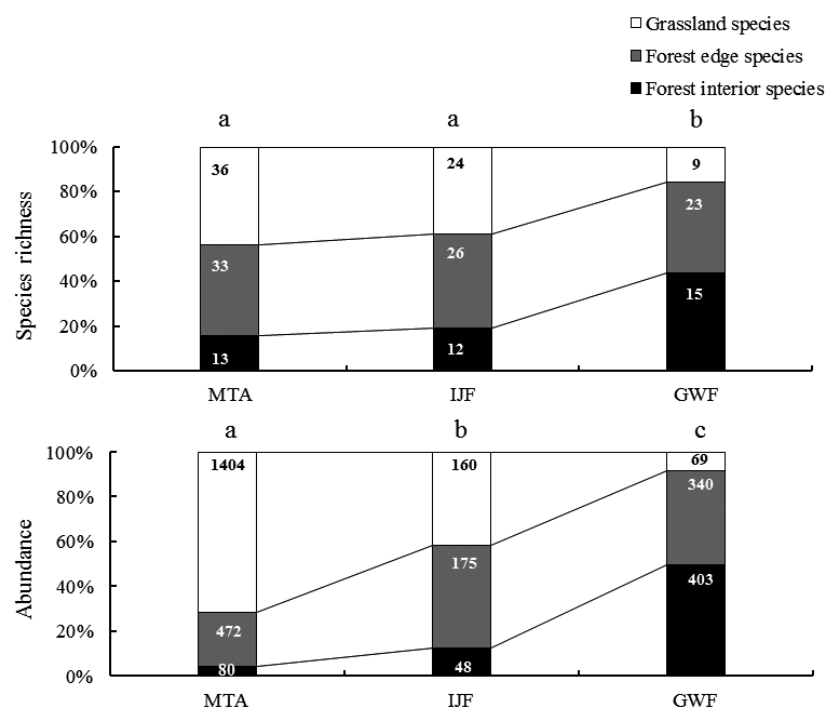

Fig. 4. The percentage of species richness and abundance of butterflies in habitat type recorded at the different sites studied. Different letters on graphs indicate significant differences among sites studied based on $\chi^{2}$-tests between two sites. The numbers in the columns indicate species richness (number of species) and abundance (number of individuals).
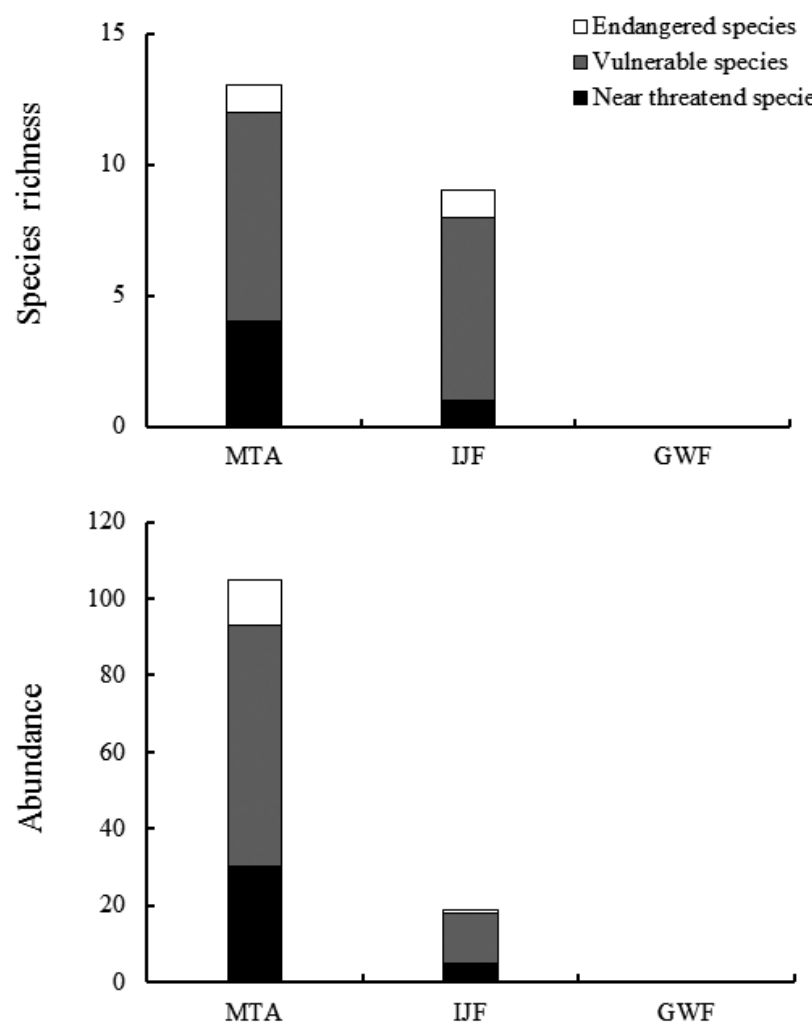

Fig. 5. Species richness and abundance of red listed species recorded at the different sites studied.

protomedia, an EN, was recorded in MTA and IJF. In the VU category, Gonepteryx maxima, Satyrium w-album, Ochlodes similis and $O$. venatus were recorded only in MTA. Coenonympha hero, Erebia wanga and Boloria oscarus were recorded only in IJF. In the NT category, Gonepteryx aspasia, Lycaena dispar, and Neptis andetria were recorded only in MTA.

The ordination plot of butterfly communities showed a clear separation based only on the sites studied (Fig. 6). The two main axes explained 27.7 and $6.6 \%$ of the total variance. The first axis was correlated with forest $(r=0.624)$, open land $(r=-0.564)$, dirt road $(r=-0.619)$, asphalt road $(r=-0.832)$ and river $(r=-0.619)$.

\section{DISCUSSION}

The results confirmed our hypothesis that species richness and abundance of red listed species are highest in MTA. Also, species richness and abundance of habitat type in MTA was significantly different and species diversity in MTA was significantly higher than in GWF. Butterfly communities differed greatly among the sites studied. In Korea, there are many military training areas because of the prevailing political problems on the Korean peninsula. MTAs for maneuvers involving large-vehicles and shelling cover a large area and negatively affect a variety of terrestrial ecosystems (Quist et al., 2003). There are reductions in native plants, perennial grasses and increases in the abundance of introduced species in the plant communities, and an increase in the area of bare soil in MTAs (Wilson, 1988; Milchunas et al., 2000; Quist et al., 2003; Gaertner et al., 


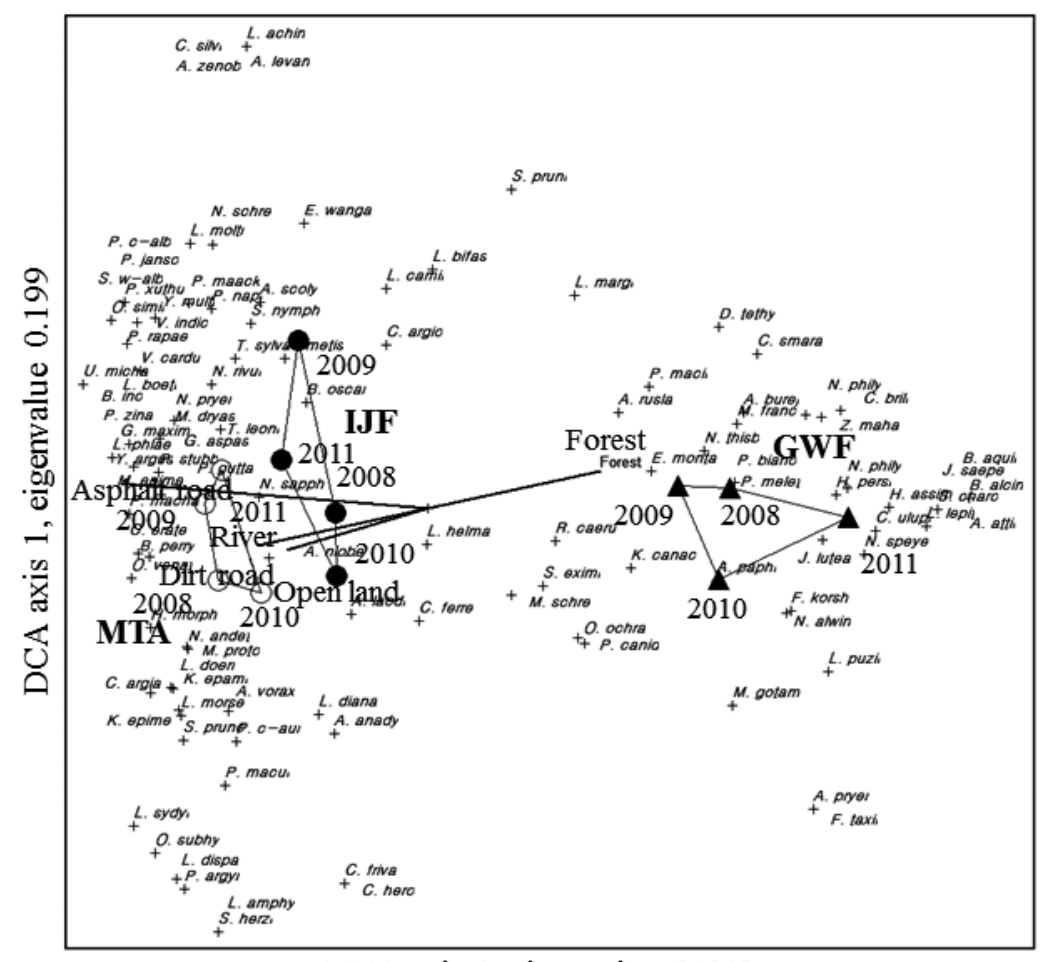

DCA axis 1 , eigenvalue 0.742

Fig. 6. Ordination of the butterfly communities based on detrended correspondence analysis (DCA). Vectors indicate environmental features with an axis correlation $r^{2}>0.3$. The small letters indicate the position of each species of butterfly.

2010). However, MTAs are considered important ecological reserves. The military practices create the habitat patches and habitat connectivity needed for the maintenance of metapopulations of endangered insects (Warren \& Büttner, 2008). The proportion of lupine stems with damage caused by Karner blue butterfly larvae, an endangered species, was greater in areas where military vehicles had traveled than where they had not (Smith et al., 2002). Smith et al. (2002) show that abundance of nectar producing plants is higher in areas traveled by tracked vehicles than in those unaffected by tracked vehicles. Military activities with tanks and armored vehicles continually create and maintain open landscapes. These open habitats will lead to an increase in GL. Of the 13 red listed species recorded in MTA, 9 species $(69 \%)$ were recorded in GL. Our result indicate that the MTA is one of the areas with the greatest number of red listed grassland species in Korea (Kim et al., 2012). This study indicates that MTAs have an important role as refuges for conservation and the maintenance of red listed grassland species.

Recently, grasslands have only accounted for $0.4 \%$ (39,371 ha) of the total land area in Korea (Ministry of Land, Transport and Maritime Affairs, 2011). Korea is one of the nations that successfully reforested after World War II. Korean government promoted an extensive reforestation program for about 30 years between 1970s and 1990s (Lee \& Kwon, 2014). In addition, the Korean economy grew during this period and the major energy source changed from firewood to fossil fuels (Kwon et al., 2010). As a result, most of the mountainous areas that were denuded or grass-covered in the 1960s are now forested (Bae \& Lee,
2006). This environmental change would have affected the species composition of the butterfly community. In this study, red listed species in GL, such as Lycaena dispar, Ochlodes similis, and $O$. venatus, were found only in MTA. These species are found at approximately 20 sites in Korea (Kim et al., 2012). Choi \& Kim (2012) show that the cause of decline in Korean endangered species is climate change, over collecting, forest succession, grassland loss and loss of symbiont ants. The main cause of the decline of 13 endangered species of butterflies, such as Lycaeides subsolanus, Argynnis aglaja, and Coenonympha amaryllis, is loss of grassland (Choi \& Kim, 2012). Melitaea protomedia, Boloria oscarus, Boloria perryi and Ochlodes similis, red listed species in GL, which were recorded in this study are found at fewer than 10 sites in Korea (Kim et al., 2012). The habitat of M. protomedia is semi-natural grassland maintained mainly as pasture or meadow and this butterfly has become rarer due to the abandonment of management of grassland in Japan (Nakamura, 2011). In Japan, voluntary-based mowing assists the conservation of $M$. protomedia (Nanba, 2009). Boloria is restricted to cooler regions in the northern hemisphere (Simonsen et al., 2010). In Korea, the decline of Boloria may be due to the effect of climate change and loss of grassland (Choi \& Kim, 2012). Boloria oscarus is recorded in grassland following a forest fire (Kwon et al., 2013). Although there is no ecological information on Ochlodes similis, the decline of this species is also likely to be due to loss of grassland. Grassland should be conserved and maintained in order to keep a high butterfly diversity within forest ecosystems (Lee et al., 2014). In contrast to records of red listed species 
in MTA and IJF, there were no red listed species recorded in GWF. This result is significant, because GWF is one of the most important conservation areas in Korea. The vegetation in GWF is composed of old growth forest because it has been conserved as a mausoleum forest for about 450 years. However, red listed species recorded in FI and FE were not recorded in GWF. Lee \& Kwon (2014) report that red listed species, such as Leptidea amurensis and Argynnis Niobe, were recorded after clear cutting at Jukyeob-san, Gwangneung Forest. Cizek et al. (2013) show that butterfly richness is higher in MTAs, but reserves host more endangered butterflies in the Czech Republic. Reserves protect rare or declining habitats such as oligotrophic wetlands, eutrophic wetlands, or warm grasslands and their associated butterflies (Cizek et al., 2013). Some butterflies may even decline in abundance in some reserves because of too meticulous management. Thus, butterfly diversity is not always high in conservation areas as these areas need to be disturbed occasionally in order to maintain their butterfly diversity.

In Korea, butterflies in GL declined dramatically compared to their prior abundance due to loss of grassland (Kwon et al., 2010, 2012). Of the 69 butterflies red listed by the National Institute of Biological Resources (2012), 37 are GL species and make up 54\% of the red listed species. In Japan, grassland butterflies are the most threatened and have declined most widely, with an extremely high rate of decline of over $80 \%$ in 40 years (Nakamura, 2011). The main cause is a change in the traditional landscape, which included secondary woodland, grassland, paddy fields and other habitats. The Japan Butterfly Conservation Society (JBCS) founded in 2004 to halt this decline, carries out various activities such as scientific research and monitoring, protection and management of habitats, campaigns and produces pamphlets (Nakamura, 2011). The awareness of the need to restore grassland is increasing and a National Grassland Restoration Network was founded in 2007 (Nakamura, 2011). In contrast, in Korea, there are no conservation activities for Korean red listed species, except those of a voluntary group for Parnassius bremeri. The expectation is that many more GLs will be threatened and lost as occurred in Japan. However, many military camps and MTAs including the DMZ inadvertently conserve and create grasslands. Further scientific studies and monitoring are required to clarify the current status of biodiversity in military areas.

\section{CONCLUSIONS}

The results indicate there is a high butterfly diversity and a large number of red listed species in MTAs. In contrast, no red listed species were recorded in GWF, which is one of most conserved areas in Korea. GL species were most abundant in MTA. This study fills an important gap in our understanding of the effects of military activity and conservation areas in forest ecosystem. However, we do not wish to imply that military activity is an ideal form of disturbance. Korean government tries to conserve and maintain diversity and distinctive features of species ac- cording to the $3^{\text {rd }}$ national biodiversity strategy and action plan (Ministry of Evironment, 2014). However, there is a lack of conservation of open habitats in and around the forest ecosystem, except for alpine wetlands and the DMZ (Ministry of Evironment, 2014). There is a need for long term plans to conserve and manage grasslands in military areas connected with the $\mathrm{DMZ}$ in order to conserve biodiversity for the future.

ACKNOWLEDGEMENTS. This study was conducted as part of a research project of the Korean Forest Research Institute (Project FE 0100-2009-01, Effect of climate change on forest ecosystem and adaptation of forest ecosystem). We thank two anonymous reviewers for their helpful suggestions.

\section{REFERENCES}

Althoff D.P., Rivers J.W., Pontius J.S. \& Woodford P.B. 2004: A comprehensive approach to identifying monitoring priorities of small landbirds on military installations. - Environ. Manag. 34: 887-902.

BAE J.S. \& LEE K.B. 2006: Impacts of the substitution of firewood for home use on the forest greening after the 1945 liberation of Korea. - J. Korean For. Soc. 95: 60-72.

Byun B., Hong S.-K. \& Song I.-J. 2005: People's consciousness survey on the nature conservation and ecological characteristic of DMZ and surrounding area. - Geogr. J. Korea 2: 221-232.

Cног S.-W. \& KIм S.-S. 2012: The past and current status of endangered butterflies in Korea. - Entomol. Sci. 15: 1-12.

Cizek O., Vrba P., Benes J., Hrazsky Z., Koptik J., Kucera T., Marhoul P., Zamecnik J. \& Konvicka M. 2013: Conservation potential of abandoned military areas matches that of established reserves: Plants and butterflies in the Czech Republic. - PLoS 8: e53124.

Clark P.J., Reed J.M. \& Chew F.S. 2007: Effects of urbanization on butterfly species richness, guild structure, and rarity. - Urban Ecosyst. 10: 321-337.

Cohn J.P. 1996: New defenders of wildlife. - Bioscience 46: $11-14$.

Colwell R.K. 2005: Estimate S: Statistical Estimation of Species Richness and Shared Species from sSmple. Vers. 7.5. User's Guide and application published at: http://viceroy.eeb.uconn. edu/estimates. Accessed 8 March 2005.

Colwell R.K., MaO C.X. \& Chang J. 2004: Interpolating, extrapolating, and comparing incidence-based species accumulation curves. - Ecology 85: 2717-2727.

EUROPA 2014: Habitats Directive. http://ec.europa.eu/environment/nature/legislation/habitatsdirective/index_en.htm. Accessed 21 November 2014.

Gaetner M., Konold W. \& Richardson D.M. 2010: Successional changes on a former tank range in eastern Germany: Does increase of the native grass species Molinia caerulea cause decline of less competitive Drosera species? - J. Nat. Conserv. 18: $63-74$.

GazenBeer A. 2005: LIFE, Natura 2000 and the Military. European Commission, Environment Directorate General, Brussels, $86 \mathrm{pp}$.

Heltshe J.F. \& ForRester N.E. 1983: Estimating species richness using the jackknife procedure. - Biometrics 39: 1-12.

Hill M.O. \& Gauch H.G. 1980: Detrended correspondence analysis: an improved ordination technique. - Vegetatio 42: 47-58.

Honda K. \& Kato Y. 2005: Biology of Butterflies. University of Tokyo Press, Tokyo, 626 pp. 
Hong K.D. 2008: Constructing a desirable military power for the $21^{\text {st }}$ century. - Defense Policy Analysis 81: 41-82.

IUCN (InTERnational Union for Conservation of Nature AND Natural Resources) 1996: Tanks and Thyme - Biodiversity in Former Soviet Military Areas in Central Europe. IUCN, Gland, Switzerland, $136 \mathrm{pp}$.

Jentsch A., Friedrich S., Steinlein T., Beyschlag W. \& NezADAL W. 2008: Assessing conservation action for substitution of missing dynamics on former military training areas in Central Europe. - Restor. Ecol. 17: 107-116.

Kim S.-S. \& Seo Y.H. 2012: Life Histories of Korean Butterflies. Sagyejel, Paju, 538 pp. [in Korean].

Kim S.-S., Lee C.M., Kwon T.-S., Joo H.Z. \& Sung J.H. 2012: Korean Butterfly Atlas 1996-2011. Korea Forest Research Institute, Korea Disabled Human Good Life Publ., Seoul [in Korean].

Korean National Arboretum 2008: Korean National Arboretum. 11-1400119-000060-01 [in Korean].

Korean National Arboretum 2014: Korean National Arboretum. http://eng.kna.go.kr/eng/.

Kwon T.-S., Kim S.-S., Chun J.H., Byun B.-K., Lim J.-H. \& Shin J.H. 2010: Changes in butterfly abundance in response to global warming and reforestation. - Commun. Ecosyst. Ecol. 39: $337-345$.

Kwon T.-S., Lee C.M., Kim S.-S. \& Sung J.H. 2012: Distribution Change of Korean Butterflies 1938-2011. Korea Forest Research Institute, Samsung Adcom, Seoul [in Korean].

Kwon T.-S., Kim S.-S., Lee C.M. \& Jung S.J. 2013: Change of butterfly communities after forest fire. - J. Asia-Pac. Entomol. 16: 361-367.

Kwon T.-S., LeE C.M. \& KIM S.-S. 2014: Northward range shifts in Korean butterflies. - Climat. Change 126: 163-174.

Lee C.M. \& Kwon T.-S. 2014: Change of butterfly communities after clear cutting in Gwangneung Forest. - Korean J. Appl. Entomol. 53: 347-354.

Lee K.J., Jo J.C., Lee B.S. \& Lee D.S. 1990: The structure of plant community in Kwangnung Forest (I). - J. Korean For. Soc. 79: 173-186.

Lee C.M., Kwon T.-S., Kim S.-S., Sohn J.-D. \& Lee B.-W. 2014: Effects of forest degradation on butterfly communities in the Gwangneung Forest. - Entomol. Sci. 17: 293-301.

Lee C.M., Park J.W., Kwon T.-S., Kim S.-S., Ryu J.W., Jung S.J. \& LEE S.K. 2015: Diversity and density of butterfly communities in urban green areas: an analytical approach using GIS. —Zool. Stud. 54: 90.

Leyer I. \& Wesche K. 2007: Multivariate Statistik in der Ökologie. Springer, Berlin, $232 \mathrm{pp}$.

McCune B. \& MefFord M. 1999: PC-ORD. Multivariate Analysis of Ecological Data. Vers. 4.0. MjM Software Design, Gleneden Beach, OR, $237 \mathrm{pp}$.

Milchunas D.G., Schulz K.A. \& Shaw R.B. 2000: Plant community structure in relation to long-term disturbance by mechanized military maneuvers in a semiarid region. - Environ. Manag. 25: 525-539.

Ministry of Environment 2014: The Biodiversity of Korea. Ministry of Environment, Sejong.

Ministry of Land, Transport and Maritime Affairs 2011: Yearbook of 2010. Ministry of Land, Transport and Maritime Affairs, Seoul.

NAKAMURA Y. 2011: Conservation of butterflies in Japan: status, actions and strategy. - J. Insect Conserv. 15: 5-22.

NANBA M. 2009: Ecology and conservation of Melitaea protomedia in Ombara Highland, Okayama Prefecture. In Mano T. \&
Fujii H. (eds): Decline and Conservation of Butterflies and Moths in Japan VI. Lepidopterological Society of Japan, Tokyo, pp. 39-40 [in Japanese].

National Institue of Biological Resources 2012: Red Data Book of Endangered Insects in Korea I. 11-1480592-00040801 .

National Institute of Environmental Research 2012: Ecological Study in DMZ and Surrounding Area. National Institute of Environmental Research, Incheon.

Palmer M.W. 1990: The estimation of species richness by extrapolation. - Ecology 71: 1195-1198.

Pollard E. \& Yates T.J. 1993: Monitoring Butterflies for Ecology and Conservation. Chapman \& Hall, London, 274 pp.

Quist M.C., Fay P.A., Guy C.S., Knapp A.K. \& Rubenstein B.N. 2003: Military training effects on terrestrial and aquatic communities on a grassland military installation. - Ecol. Appl. 13: 432-442.

Reif J., Marhoul P., ČížEK O. \& KonvičKa M. 2011: Abandoned military training sites are an overlooked refuge for at-risk open habitat bird species. - Biodivers. Conserv. 20: 3645-3662.

Shannon C.E. \& Weaver W. 1949: A Mathematical Theory of Communication. University of Illinois Press, Urbana, IL, 125 pp.

Simonsen T.J., Wahlberg N., Warren A.D. \& Sperling F.A.H. 2010: The evolutionary history of Boloria (Lepidoptera: Nymphalidae): phylogeny, zoogeography and larval-foodplant relationships. - Syst. Biodivers. 8: 513-529.

Smith M.A., Turner M.G. \& Rusch D.H. 2002: The effect of military training activity on eastern lupine and the Karner blue butterfly at Fort McCoy, Wisconsin, USA. - Environ. Manag. 29: 102-115.

StatSoft Inc. 2004: Statistica for Windows. Vers. 6. Statsoft Inc., Tulsa, OK.

THOMAS C.D. 1995: Ecology and conservation of butterfly metapopulations in the fragmented British landscape. In Pullin A.S. (ed.): Ecology and Conservation of Butterflies. Chapman and Hall, London, pp. 46-64.

Thomas J.A., Telfer M.G., Roy D.B., Preston C.D., Greenwood J.J.D., Asher J., Fox R., Clarke R.T. \& Lawton J.H. 2004: Comparative losses of British butterflies, birds, and plants and the global extinction crisis. - Science 303: 1879-1881.

van Swahy C., Cuttelod A., Collins S., Maes D., López Munguira M., Šašić M., Settele J., Verovnik R., Verstrael T., Warren M., Wiemers M. \& Wynhoff I. 2010: European Red List of Butterflies. Publications Office of the European Union, Luxembourg, $48 \mathrm{pp}$.

WARREN S.D. \& BÜTTNER R. 2008: Active military training areas as refugia for disturbance-dependent endangered insects. $-J$. Insect Conserv. 12: 671-676.

Warren S.D., Holbrook S.W., Dale D.A., Whelan N.L., Elyn M., Grimm W. \& Jentsch A. 2007: Biodiversity and the heterogeneous disturbance regime on military training lands. Restor. Ecol. 15: 606-612.

WILSON S.D. 1988: The effects of military tank traffic on prairie: a management model. — Environ. Manag. 12: 397-403.

Yамамото Y. 1975: Notes on the methods of belt transect census of butterflies. - J. Fac. Sci. Hokkaido Univ. (Zool.) 20: 93-116.

Zar J.H. 1999: Biostatistical Analysis, 4th ed. Prentice Hall International, Upper Saddle River, NJ.

Received July 10, 2015; revised and accepted August 27, 2015 Prepublished online September 22, 2015 
ApPENDIX 1. Butterflies observed at the study sites from 2008 to 2011. See text for classification methods of habitat type and red list species of butterfly. Habitat type: GL - grassland species, FE - forest edge species, FI - forest interior species. Red list species: EN - endangered species, VU - vulnerable species, NT - near threatened species.

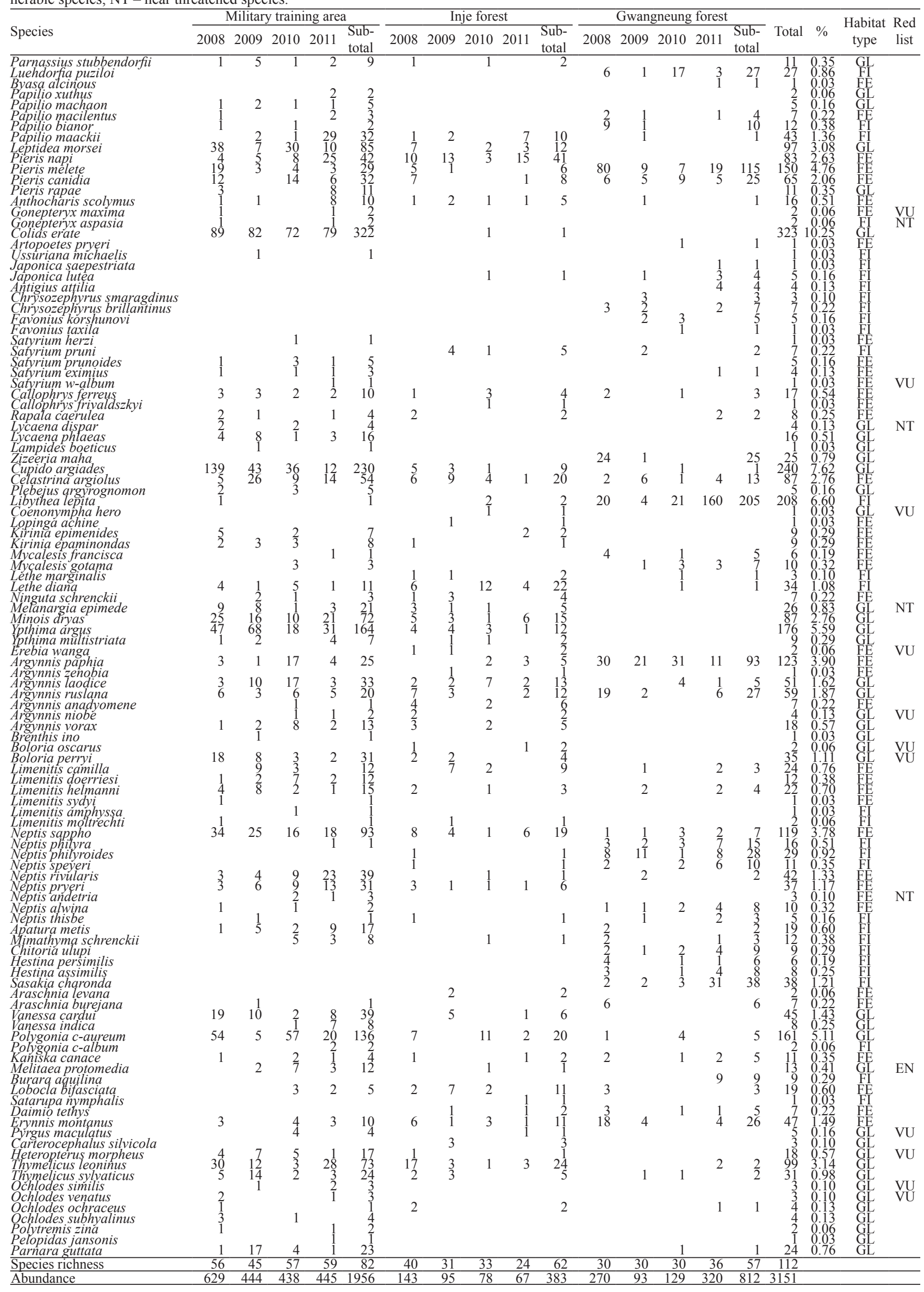

